\begin{tabular}{|c|c|c|c|}
\hline & \multicolumn{2}{|c|}{ R\&S - RESEARCH STUDIES ANATOLIA JOURNAL } & 6 \\
\hline $\begin{array}{l}\text { Researeh Studies } \\
\text { Anatolia Journal }\end{array}$ & https://dergipark.org.tr/rs & Vol:4 Issue:2; pp:115-129 & $\frac{1}{2+x}$ \\
\hline
\end{tabular}

SOCIAL AND HUMAN SCIENTIFIC

Sümerli Sarıgül, S. \& Coşkun, A. (2021). "Balanced Scorecard (BSC) as a Strategic Performance Management Tool: Application in a Multinational Bank", R\&S -Research Studies Anatolia Journal, Vol:4 Issue:2; pp:115-129

Anahtar Kelimeler: Kurumsal Karne, Yönetim Keywords: Balanced Scorecard, Management Muhasebesi, Performans Yönetimi, Stratejik Yönetim Accounting, Performance Management, Strategic Management

Makale Türü Araștırma Makalesi

\title{
BALANCED SCORECARD (BSC) AS A STRATEGIC PERFORMANCE MANAGEMENT TOOL: APPLICATION IN A MULTINATIONAL BANK
}

\author{
Bir Stratejik Yönetim Aracı Olarak Kurumsal Karne: Çok Uluslu Bir Banka \\ Uygulamasl
}

Sevgi SÜMERLİ SARIGÜL ${ }^{1}$

Ahmet COŞKUN ${ }^{2}$

\begin{abstract}
Geliş Tarihi / Arrived Date $02 / 03 / 2021$ $19 / 03 / 2021$

öZ

Bu çalışmanın amacl, Balanced Scorecard (BSC) yönteminin bir stratejik performans ölçüm yaklaşımı olarak nasıl kullanıldığını göstermek ve başarılı bir uygulama örneğini paylaşmaktır. Bu çalışmada, modern performans yöntemlerinden biri olan Balanced Scorecard (BSC) yöntemine ilişkin teorik bilgiler verilmiştir. Ayrıca, stratejik bir performans yönetim aracı olarak BSC yönteminin uygulanması, Türkiye'deki çok uluslu bir bankada gerçek bir uygulama örneği ile ayrıntılı olarak adım adım açıklanmıştır. BSC sisteminin ana yapısının oluşturulması ve şirket stratejileri ile bağlantılar, sorumlu is biriminin kurulması ve rolleri, kurumsal karnelerin ve KPI'ların olușturulması, KPI'ların ayrıntılı tanımlanması, BT Destekli BSC Yönetim Sisteminin kurulması ve son olarak karnelerin raporlanması gerçek örneklerle gösterilmiştir. İlgili gerçek vaka örneği, BSC yöntemini kullanan çokuluslu bankanın, Türkiye bankacılık sektöründe 2010 yılında 24. sıradan 2020 yılında 10. sıraya yükselerek stratejik hedeflerini başardığını göstermektedir. Hem teorik modelin, hem de uygulama vaka örneğinin paylaşıldığı bu çalışma, gerek akademik alana katkıda bulunacak, gerekse iș dünyasında uygulayıcılara BSC'yi stratejik yönetim süreçlerinde uygulamalarına destek olmak bakımından faydalı bir çalışma olacaktır.
\end{abstract}

Kabul Tarihi / Accepted Date
Yayınlanma Tarihi / Published Date $30 / 04 / 2021$

\section{ABSTRACT}

The purpose of this study is to reveal a successful application process of Balanced Scorecard (BSC) method as a strategic performance measurement approach. In this study, theoretical information is given regarding the Balanced Scorecard (BSC) method which is one of the most modern methods. Additionally, the implementation of the BSC method, as a strategic performance management tool, will be explained in detail by a real practice example in a multinational bank in Turkey. The creation of the main structure of the BSC system and interlinkages with the company strategies, the establishment and roles of business unit, the creation of scorecards and KPIs, detailed definition of the KPIs, the establishment of IT-Aided BSC Management System and finally reporting of the scorecards is shown with real examples. The real case example shows that the multinational bank using the BSC method succeeded its strategic objectives by raising their rankings in the banking sector of Turkey from 24th place in 2010 to 10th place in 2020. Providing such information, this study would be a beneficial example of contributing the academic field and supporting the business organizations to apply the BSC in their strategic management processes.

1 iD Dr. Öğr. Üyesi, Kayseri Üniversitesi, Teknik Bilimler MYO, ssumerli@kayseri.edu.tr, Kayseri/Türkiye 


\section{INTRODUCTION}

Business management has four basic functions: Planning, organization, management and control. Performance measurement and management is the most important activity of management's control function. Performance measurement helps managers determine how successful their organizations are and make the right decisions about the future of their business. Performance measurement enables the control, evaluation and improvement of processes and outputs and helps to determine the extent of deviations from goals by comparing pre-determined goals with actual results.

It can be said that in today's competitive environment, there is no performance measurement system that can fully meet the needs of management. Because, it is seen that many businesses use only financial-based performance measurement models, adhere to short-term performance indicators and cannot establish the balance between factors affecting business performance. The traditional methods place too much emphasis on short-term financial results. So, in the long run, investments that create value increase such as growth are not monitored in a well manner due to these short-term biases.

Robert S. Kaplan from Harvard Business School and David Norton from the Renaissance Consulting Company, in 1990, asserted that traditional financial measures alone are not useful enough, and with the support of the Nolan Norton Institute in the United States, they started a research named "Measuring Performance in the Organization of the Future" (Sümerli Sarıgül and Savsar, 2018: 132).

The basis of this research is the idea that performance measures based on financial indicators are now incompetent to show the real performance of a company. For this project, representatives of enterprises operating in different fields such as production, service, heavy industry and advanced technology gathered once a month for a year and worked together to develop a new performance measurement method (Calabro, 2001: 73). The outcome of these studies was developed and named Balanced Scorecard (BSC) to ensure the capability of performance management systems to provide relevant and comprehensive data including different aspects of an organization.

Accordingly, the main goal of this paper is to show a real business application case of BSC in a multinational bank example after giving a brief definition theoretical framework of the topic. Hopefully, this study might serve as a relevant contribution to the field for both academicisians and practitioners, as there is seen a lack of practical examples about BSC implications in real business organizations.

\section{Definition, Scope and Importance of Balanced Scorecard}

The Balanced Scorecard entered the management literature with the article "The Balanced Scorecard Measures That Drive Performance", first published in the Harvard Business Review magazine in 1992 (Kaplan and Norton). In 1993 Kaplan and Norton published the "Putting the Balanced Scorecard to Work" article in Harvard Business Review, and explained how it has been successfully applied in many businesses (Lopes, 1996: 7). Followingly, "Translating Strategy into Action: The Balanced Scorecard" book was published (Kaplan and Norton, 1996a), in which the research results of this rigorous study were revealed (Niven, 2002: 11).

In 1996, it appeared as the model in Figure 1 with the article "Using the Balanced Scorecard as a Strategic Management System" (Kaplan and Norton, 1996b). With this study, Kaplan and Norton initially defined the balanced scorecard as the performance evaluation method; they started to define it as a strategic management model (Griffiths, 2003: 71).

Kaplan and Norton describe the BSC, which they developed upon recognizing the shortcomings of performance measurement systems based on financial measures, as follows: "BSC creates a framework for strategic measurement and management by translating the organization's mission and strategy into a detailed set of performance measurement" (Kaplan and Norton, 1992: 71). BSC is a tool for focusing on the organization in a holistic sense, improving communication,

\section{$\mathrm{R} \& S$}

Research Studies Anatolia Journal

Volume:4, Issue:2, April 2021 
determining organizational goals and providing strategic feedback (Gautreau and Kleiner, 2001: 153). The BSC method, which was originally designed with profit-oriented enterprises in mind, has become widespread in time and has been used in non-governmental organizations and public institutions as well (Cullen et al., 2003: 7).

The concept of BSC has emerged as a management tool that controls the implementation of the medium and long-term strategies of the enterprise by the employees and observes the progress during this process. BSC aims to make the strategies of the enterprise into concrete figures that can be measured and to classify these parameters in a more useful manner. Thanks to the BSC approach, the long-term goals of organization are to be constantly under the spotlight. The purpose of BSC is to enable managers and employees to focus on business strategies and key issues that are important for organization (Ağça and Tunçer, 2006: 182).

Many businesses evaluate company performance only with its financial aspect. Whereas, financial measurements do not explain the connection between vital performance factors of an enterprise since they are basically aimed at measuring the past performances (Lee and On Ko, 2000: 70). The $\mathrm{BSC}$, on the other hand, takes into account not only the financial dimension, but also intangible factors that were previously considered not very valuable and immeasurable. In this sense, BSC brings an innovation to the performance measurement system of the enterprise and helps to ensure the harmony between various strategic measurements in an organization.

BSC is not only a performance measurement system, but also a management system that can direct the energy, skills and specific information of people working in an enterprise to achieve long-term strategic goals. Because traditional performance measurement systems generally do not measure the relationships between employee performance and company strategy and are primarily based on financial measurements. In this sense, BSC supports the idea that the performance of employees should be evaluated by considering their compliance with the company strategy (Gautreau and Kleiner, 2001: 153).

Figure 1. Perspectives of Balanced Scorecard

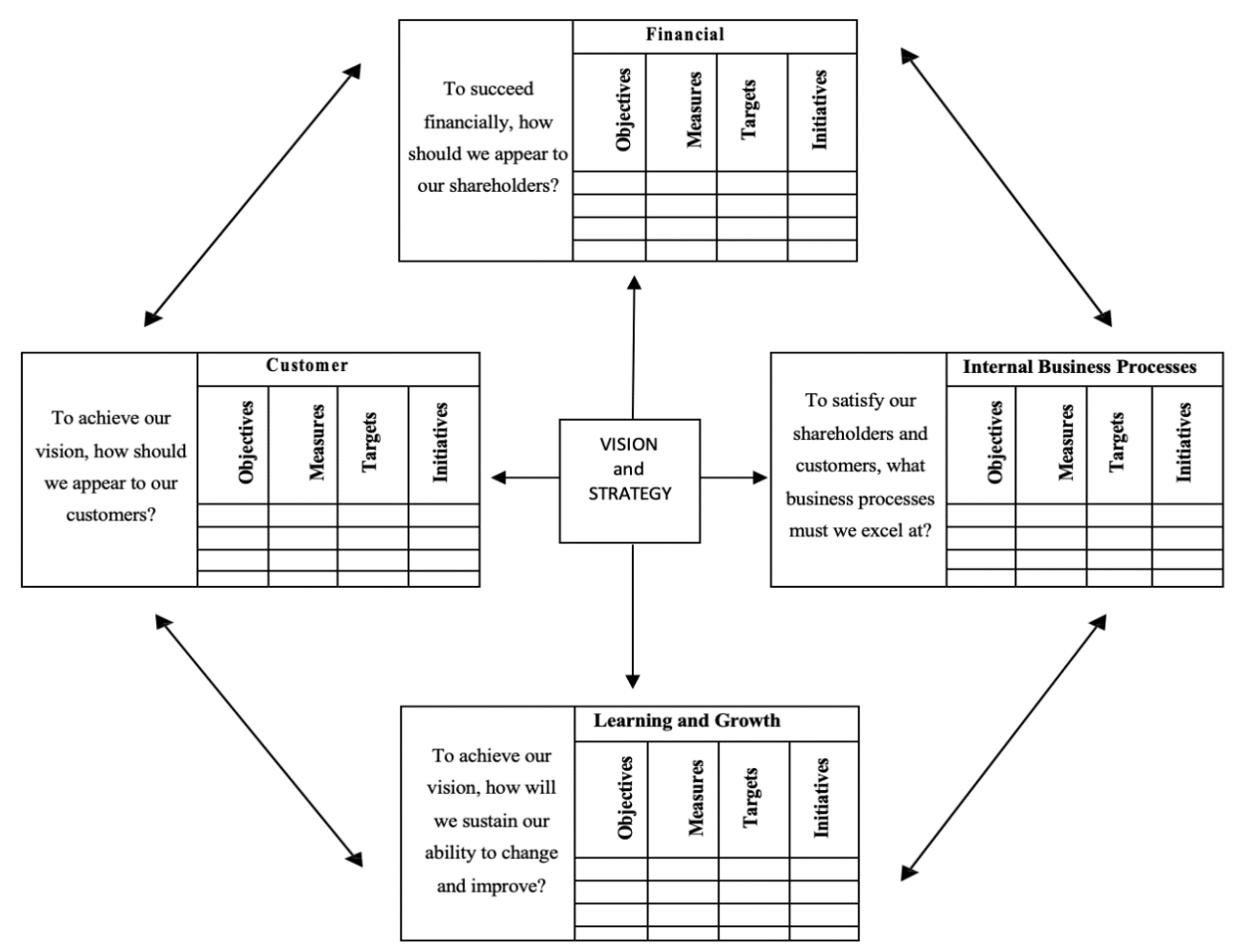

Source: Kaplan and Norton, 1996a: 76; Kaplan and Norton, 1999: 10. 
The BSC system tries to explain strategic dimensions of an organization and balance them with key performance indicators (KPIs). The key is to link the various forms of measurement to the strategy. BSC generally groups strategic metrics into four perspectives (Gautreau and Kleiner, 2001: 153-154; Walker and MacDonald, 2001: 365). These are; financial perspective, customer perspective, internal processes perspective and learning and growth perspective. The relationships between the four perspectives of the scorecard and the connections of these perspectives with the vision, mission and strategy can be seen in Figure.1.

\section{Perspectives of Balanced Scorecard}

The BSC technique offers managers the opportunity to view performance measurement from a different perspective. Four different balanced scorecard dimensions help companies to adapt to changes in different environments while providing a significant advantage in competitive markets. It is seen that the four perspectives and the goals and criteria within each are in a relationship with each other (Kaygusuz, 2005: 98). Balanced scorecard perspectives should be considered in an integrated manner to realize the company's vision and strategy. In order to prepare the scorecard, following questions about these perspectives need to be answered (Kaplan and Norton, 1997: 5-11; Neely, Bourne and Kennerley, 2000: 1120; Argüden and Sağdıç, 2000: 14):

1. What quantitative goals can our business achieve to be considered successful by our partners? (Financial Perspectives)

2. How should we be perceived by our customers in order to achieve our vision? (Customer Perspectives)

3. In which processes should we aim for excellence to satisfy our customers? (Internal Processes Perspectives)

4. What kind of a corporate learning and growth model should we have to reach our vision? (Learning and Growth Perspectives)

As there are mutual logical relations between the four perspectives of the balanced scorecard, each dimension also has a mutual relation with the vision, mission and strategies of the enterprise. According to Kaplan and Norton (2001: 23), these perspectives allow businesses to simultaneously monitor the development of skills required to acquire the intellectual capital and intangible assets they need to increase. Correspondingly, they can improve their long-term competitiveness while monitoring their financial results (Tangen, 2004: 74; Coşkun, 2006: 6). These perspectives of the balanced scorecard are discussed in detail below.

\section{Financial Perspective}

In the Balanced Scorecard, it is aimed that all departments in the organization associate their financial goals with the organization strategy. Financial objectives are the ultimate focus for the purposes and measures of all other dimensions in the Balanced Scorecard (Yllmaz, 2007: 110). For this reason, each KPI chosen must be a part of cause and effect relationships to provide an improvement in financial performance.

The financial objectives and measures that businesses will use may also differ depending on the stage of the organization's life cycle -such as growth, promotion, maturity (Güner, 2008: 254).

The financial perspective includes the evaluation of the results obtained in terms of the expectations of the shareholders (Ergün, 2002: 10). The balanced scorecard technique preserves the financial perspective features used to evaluate the economic performance of companies, in the past. Financial performance measures determine whether a firm's strategy and practices towards this strategy contribute to firm development (Kaplan and Norton, 2003: 33).

Key performance indicators and target values in the financial perspective may differ according to the sector, environment and business strategies. However, since the main priority of enterprises is the objectives in this dimension, key performance indicators and performance targets in other perspectives should be formed in a way that contributes to the achievement of one or more goals

\section{$\mathbf{R} \& S$}

Research Studies Anatolia Journal

Volume:4, Issue:2, April 2021 
in the financial perspective (Kaplan \& Norton, 1999: 60-79; Sümerli Sarıül and Savsar, 2018: 135).

The financial perspective encourages the use of traditional financial objectives related to profitability, the returns of the tangible and intangible assets used, new investments, reductions in costs and growth in revenues (Ensari, 2005: 57). In the BSC, it is accepted that the long-term objective of the company is to provide profit to the investors and the implemented company strategy should be aimed at achieving this financial objective. The determined financial target is the focal point for the goals and measures of all other perspectives in the BSC (Kaplan and Norton, 1999: 90). The objectives and measures determined within the framework of other perspectives of the company are determined as sub-targets that will have an impact on financial performance based on the cause-effect relationship (Sağmanlı and Ersen, 2001: 129).

\section{Customer Perspective}

One of the biggest structural changes brought by the new economy has been the change in the balance of power between producer, seller and customer in favor of the customer. Therefore, today's businesses have begun to develop customer-oriented strategies. Since, a high performance in the long-term can only be achieved by providing products and services that customers value (Ergün, 2002: 11; Selvi, 2007: 63; Sümerli Sarıül and Savsar, 2018: 135). Business success is not only about financial performance; but it is foreseen to be used in areas such as customer delivery time, production excellence and new product development (Akgül, 2004, 75).

Thus, the value and strategies to be provided to the customers are determined in the customer dimension of the Balanced Scorecard. After the strategy is determined, the targeted market segment and customer base are determined and the capacity of the business units to create customer satisfaction and loyalty in the target market is evaluated (Niven, 2002: 120-123). Some of the basic measures in the customer perspective of the BSC technique are market share, customer retention, customer acquisition, customer satisfaction and customer profitability (Kaplan and Norton, 1999: 86).

The products and services that businesses offer to their customers and the relationships they have established with them are valued by customers. The results of this valuation reveal how organizations make themselves attractive in the eyes of their target customers, develop and protect their relationships with them, in comparison with their competitors. Consequently, customer valuations enable businesses to improve their output by helping to connect their customers with their internal processes (Amaratunga et all., 2000: 70).

\section{Internal Business Process Perspective}

After the financial perspectives and customer perspecives are selected and the appropriate measures are determined, the internal processes that the business should perfect are determined. Internal processes are internal methods that will ensure that the expectations of shareholders regarding financial performance are met and the value to be presented to customers in the targeted market segment (Kaplan and Norton, 1999: 181-183).

At this stage, managers determine what are the important procedures that need to be carried out in order to fully realize their goals for partners and customers (Ergün, 2002: 11). Once the factors that will ensure customer satisfaction are identified, management should focus on critical internal processes in order to satisfy customers. In these processes, in addition to the application of tools and techniques such as just-in-time production, total quality management, activity-based costing and target costing, the effectiveness of these techniques should be ensured and improved (Kaygusuz, 2005: 94).

Companies can identify tools that can diversify customer valuation criteria and achieve financial targeted productivity growth by clearly determining their financial and customer perspectives. These tools are defined in terms of the internal processes of the BSC and are explained in four high-level processes as vital organizational factors. These are (1) privilege creation; encouraging

\section{$\mathrm{R} \& S$}

Research Studies Anatolia Journal

Volume:4, Issue:2, April 2021 
innovation to develop new products and services and reach new markets and customers; (2) increasing the value of the firm in the eyes of customers; improving relationships with existing customers, (3) realizing operational excellence; development of supply chain management, internal processes, asset utilization level, resource-capacity management and other processes; and (4) being a good company member or organization member; which is to create effective relationships with external interest groups (Özbirecikli and Ölçer, 2002: 8).

Different competition strategies lead into different internal processes perspective approaches. For example, businesses applying the strategy of operational excellence can provide competitive advantage over their competitors in terms of pricing, product quality, product selection and timely delivery. In order for a business that implements the strategy of developing good relations with customers to increase the quality of its relations, the product and service offered to each customer must be appropriate to the personal characteristics of that customer. Businesses that implement product leadership strategy should focus on the functionality, features and performance of their products and services (Kaplan and Norton, 2001: 93).

\section{Learning and Growth Perspective}

The last perspective of BSC is the learning and growth perspective, which is the basis of every business strategy. Balanced Scorecard is not just a matter for senior management. Since BSC strategy is reflected in all operations, all employees take part in the application of this approach. In this perspective, business managers define the operating skills and abilities, technology and organizational climate that support the implementation of the strategy. Objectives in the learning and growth perspective aim to assist businesses in defining the infrastructure required to achieve strategic objectives determined in other perspectives (Kaygusuz, 2005: 96). Objectives in this perspectives are the very basic initiatives that will ultimately achieve excellent results in other perspectives (Kaplan and Norton, 1999: 153).

According to Niven (2002: 16), the objectives and measures in the learning and growth perspective constitute the structure on which the BSC is built. Measures used in the perspective of learning and growth are generally related to employee retention and employee productivity, employees' skills and satisfaction, availability of information in the organization (Niven, 2002: 16; Ensari, 2005: 60).

This dimension serves for the performance development necessities of the employees, as well. Performance assessment for employees is among the most important functions of human resources management (Fındıkçı, 1999: 297). It is the effort to determine the level of fulfillment of certain tasks within a certain time frame. Thus, the person sees the results of his/her own work in a sense and evaluates the results of his/her individual success via BSC results, if the individual scorecards are implemented. According to the results obtained, it is determined to what extent the expectation of success for the person is realized. As a result of this information, various career decisions can be made for that particular employee, such as promotion, career planning, wage adjustments, job changes, job enrichment or similar decisions (Bruke and Koonce, 1997: 8).

To sum up, Balanced Scorecard foresees to consider these four dimensions in terms of the past, present and future of the business. The combination of all of them enables businesses to sustainably develop and survive in the long term. Therefore, each dimension plays an active role at least as much as the other in order for businesses to have a sustainable competitive strategic advantage in the market.

\section{APPLICATION of BSC in a MULTINATIONAL BANK}

The main purpose of this research is to illustrate how the BSC system, as a strategic performance management application, is implemented as a part of strategic management in a multinational corporate bank. In this way, both researchers and practitioners will be given an idea about how BSC can be successfully implemented in an enterprise.

\section{$\mathrm{R} \& S$}

Research Studies Anatolia Journal

Volume:4, Issue:2, April 2021 


\section{Method}

The establishment and implementation phases of the Balanced Scorecard (BSC) System will be examined in an organization that adopts the BSC approach as a strategic performance management tool to realize its long term strategic goals. This real case of balanced scorecard performance management application is investigated in a multinational financial institution operating in the Turkish banking sector for over 30 years. As of January, 2021, the company has more than 6,000 employees and nearly 450 branches.

The application info derived from the former and current employees and managers of the bank. The figures and graphs are genuine corporate documents which were used internally and to some degree confidential. Thus, some details such as the KPIs being measured and shown in Figure.5 (Example Reporting of a Scorecard) were omitted to ensure the confidentiality of the organization.

\section{Creation of the Strategic Plan}

Considering the total deposits size and branch number, the bank was on the 24th place amongst the banks in Turkey, in 2010. That year the senior management of the bank set a strategic goal to be among the Turkey's 10 largest banks by 2018 (Graph.1). Consequently, by the end of 2020, this strategic goal was achieved, which is apparently a huge success in such a competitive market. The aim of this research is to examine the steps through this success story in terms of the contribution of balanced scorecard management technique as a strategic performance management tool.

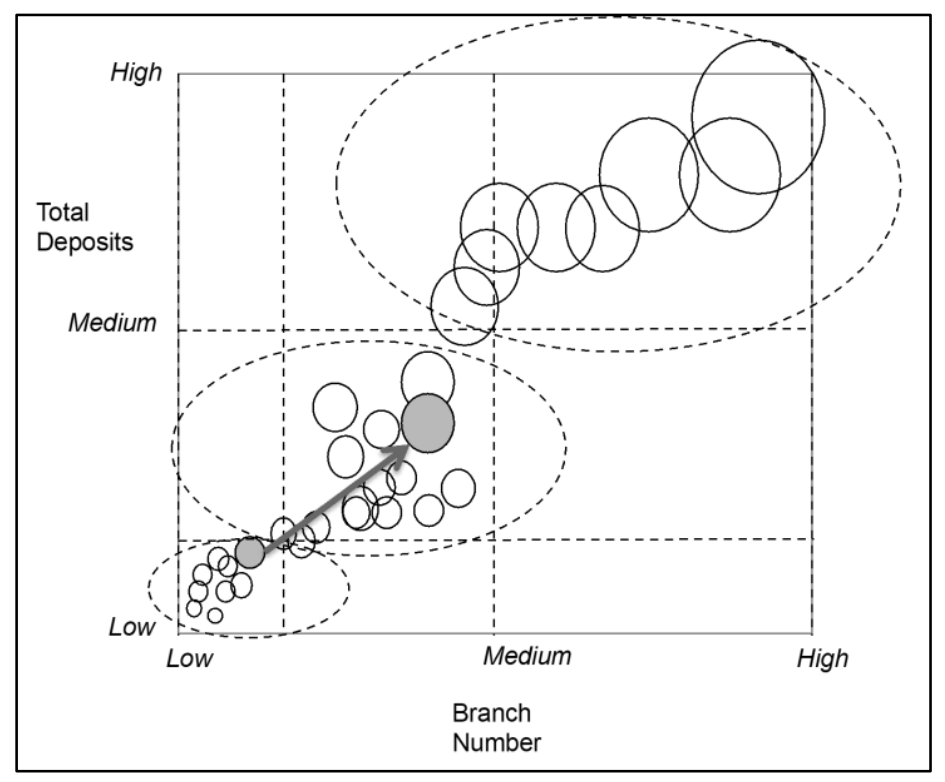

Graph 1. Strategic Growth Goal of the Company

Strategic plan preparations in the organization subject to this study were initiated in 2008 through the service procurement from an international consultancy firm. Within the scope of that study, internal and external environment analyzes were held, numerous meetings, workshops, face-to-face interviews and focus group studies were conducted with an internal and external set of stakeholders. Then, the strategic plan of the enterprise was created with the contributions of senior management and shared with internal stakeholders.

\section{Establishing SCPM Department to BSC System}

Followingly, in order to monitor the strategy and integrate it into the performance management system, a Strategic Corporate Performance Management (SCPM) Unit was established under the Quality and Organization Development Department and then it was transferred to the Human Resources Department to concord all performance management activities. The SCPM business unit has been undertaking the responsibility of managing BSC based performance system and ensuring its continuity by doing the following tasks: 
- Defining performance management methodologies and ensuring their implementation,

- Answering questions about balanced scorecards and solving relevant problems,

- Managing the process of creating new scorecards and / or updating existing scorecards and KPIs, taking into account the strategic business plan determined annually in line with the vision and strategic goals, job descriptions and updated processes on the basis of department, unit and role, working with departments to define the methodologies needed to set performance indicators,

- Determining the data needed for performance measurement. Obtaining data that is not currently available from the system manually from the relevant units in the first place, and gradually conducting joint studies with relevant units to obtain the data from the system,

- Managing the process of determining the performance indicator goals and weights, updating and communicating them to the relevant persons and units as required, in cooperation with the department and units,

- Ensuring that each KPI is measured and reported by considering the reporting frequency criterion in the relevant scorecard,

- Investigating the causes of problem in case the desired goal cannot be achieved as a result of performance evaluations,

- Managing the process of determining the improvement opportunities and action plan for KPIs that are below the target values and submitting the outputs to the approval of the senior management and the relevant unit,

- Working in coordination with the Human Resources department currently responsible for the performance management of Branches and Regions during the corporate performance management application.

\section{Aligning the BSC System with the Corporate Strategy}

This SCPM unit has created a total of more than 1,000 KPIs of the company for 77 balanced scorecards of managers at different levels, including 62 department managers, 7 group directorates, 7 vice general managers and 1 general manager. All of these unique scorecards and KPIs were connected to the strategic plan to realize the vision of the company in the long run. So, in order to establish such a relationship between BSC and overall strategic management, the bank firstly created an interlinkage framework, which is shown in below Figure 2.

Figure 2. Interlinkage Framework Between BSC and Strategic Management

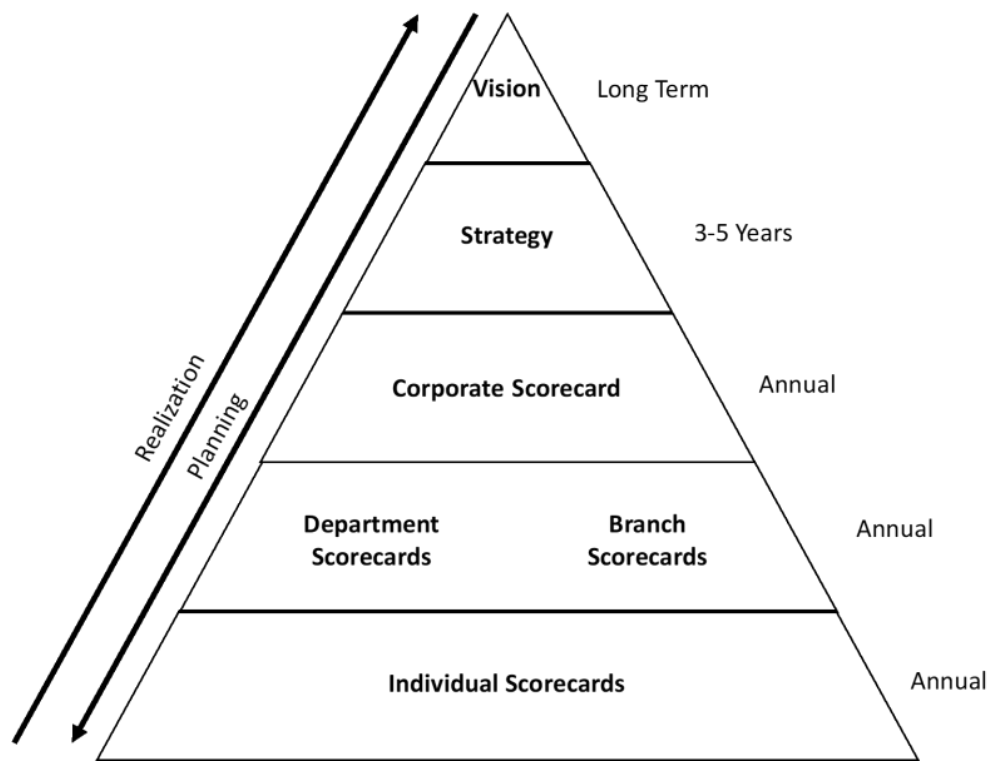

The bank has established BSC-Based SCPM System to enhance the capability of its strategic management activities. Doing so, it had an aim to share the organization's vision and strategies 
with employees by the key performance indicators. It was also planned to let all employees focus on common goals and to increase the performance and task awareness throughout the organization. Thus, the ultimate goal of the BSC-Based SCMP System is to engage individual performances with the overall performance of the company by creating a direct relationship between individual scorecards and corporate scorecard.

\section{Creating the Department Scorecards}

According to this framework firstly a BSC at the corporate level was created. Concordantly, other scorecards were created in a deductive manner to the level of departments and sub-units in the organization. To do so, all relevant KPIs were created with the participation of heads of particular business units. The following questions were asked to these business unit managers to determine the KPIs for their departments:

1. What are the goals and current performance criteria set by your department within the scope of the strategic objectives and the key performance indicators at the corporate level related to them?

2. Does your department/unit have performance criteria determined on the basis of job titles? Is any performance measurement system/approach used in your business unit/department?

3. Within the framework of corporate strategy, what are the performance criteria that you think will be beneficial and important to implement, although they are not already in your department?

4. Are there any activities currently carried out by your department/unit that are not included in the job descriptions?

5. Could you rank the main tasks performed by your department/unit in terms of importance and time allocated?

6. In which areas do you think you need improvement as a department/unit?

Figure 3. Retail Banking Product Development Department Scorecard

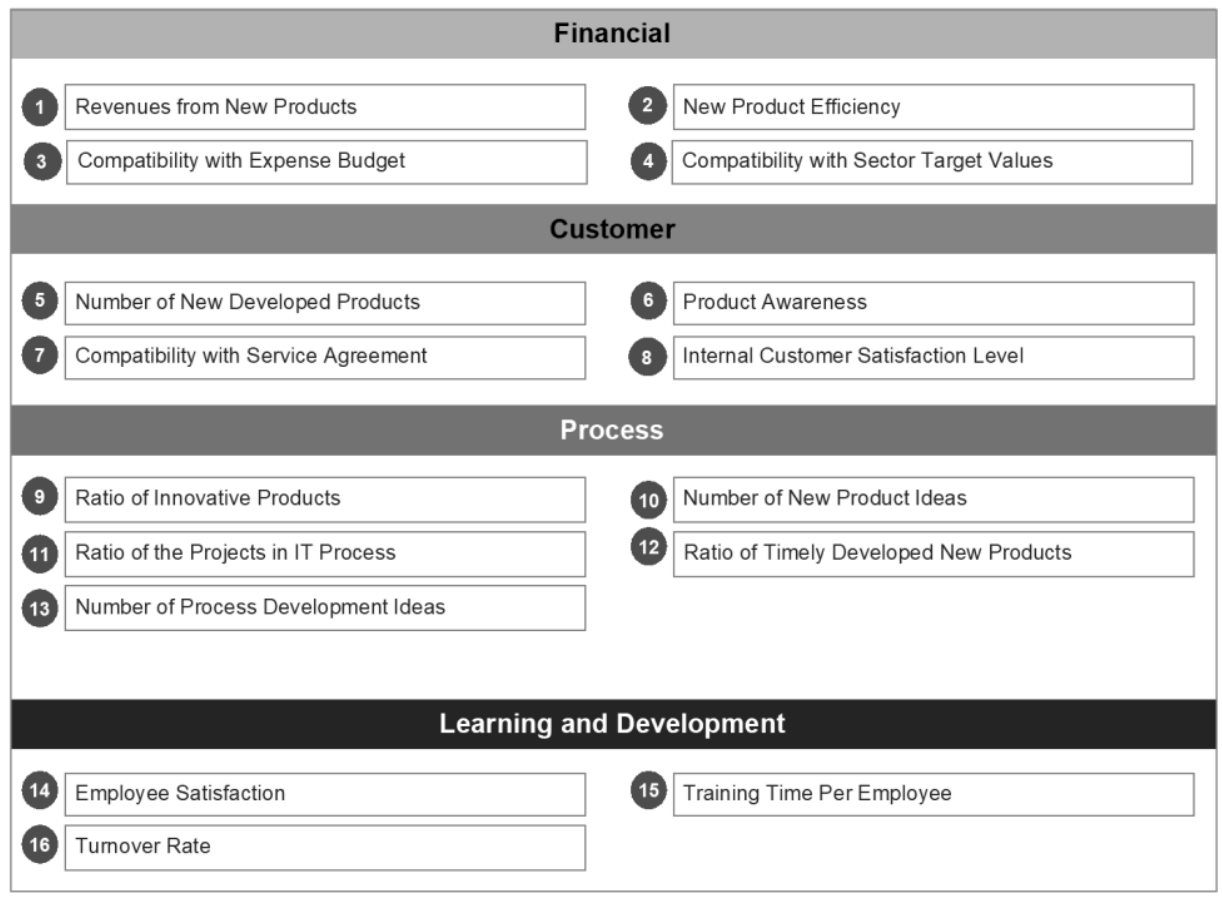

After gathering answers for above questions from each manager, balanced scorecards were formed. Balanced scorecards, which are the most important outputs of the aforementioned system were used to associate corporate strategies with a set of goals and criteria in four different dimensions with a balanced approach: "financials", "customer", "process" and "learning and 
growth". An example of the formed scorecards, the scorecard of Retail Banking Product Development Department is shown in below Figure.3. There are 16 KPIs under four performance dimensions. The KPIs were tried to be distributed to these dimensions in a balanced way. Some KPIs (e.g. Employee Satisfaction or Internal Customer Satisfaction Level) derived directly from the corporate scorecard, while some others (e.g. Revenues from New Products or Number of New Product Ideas) were about solely the outcomes of the particular department.

The company has invested a great piece of time and effort in creating these scorecards. Subsequently, preparing these scorecards it was aimed to:

- Raise the awareness throughout the organization on short and medium-term strategies determined by senior management within the framework of the vision,

- Transform these strategies into measurable targets at corporate, department and sub-unit levels, thus ensuring that each organization unit focuses on common strategic goals within the framework of its tasks and responsibilities.

- Determine certain targets in terms of financial, customer, process, learning and growth areas that support the realization of these overall goals.

- Monitor the performances of corporate, department and sub-unit performances objectively and effectively, through key performance indicators defined in direct relation with these targets.

- And, finally provide input to the individual performance management system recommended to be established in the following period.

\section{Defining the KPIs}

It was also important that each balanced scorecard include critical information such as definitions, formulas, data needs and supply methods, reporting frequency and detail level regarding key performance indicators. In order to assure that necessity, a detailed KPI information card (Figure.4) was created for each indicator including the aforementioned details and further. An example illustration of all relevant explanations regarding the balanced scorecard and the various sections that were included in the scorecard is given below.

Figure 4. KPI Information Card

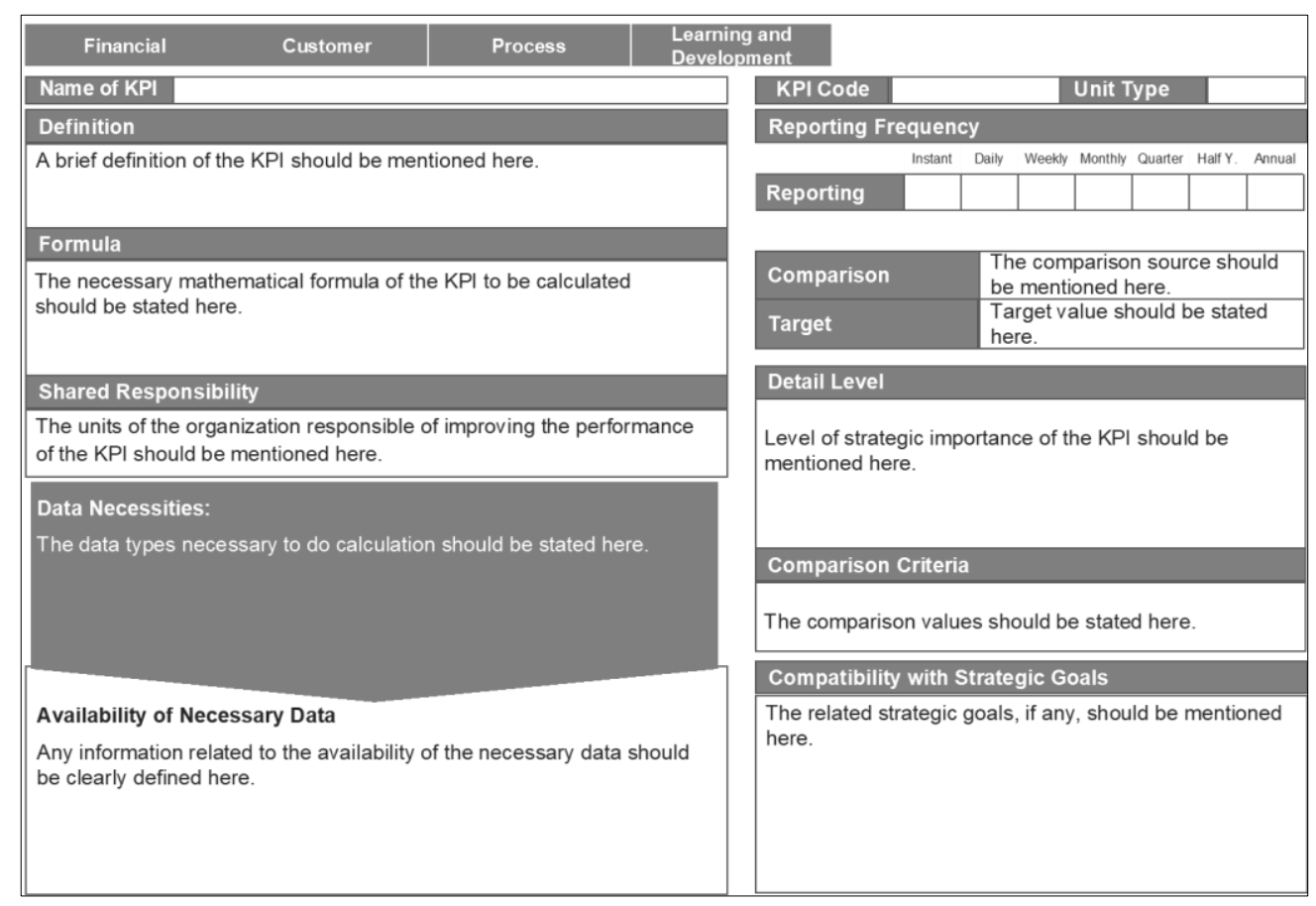


While determining the KPIs, these details were taken into consideration:

- It should be related to the goals and/or projects in the Strategic Business Plan.

- Job descriptions, roles and responsibilities should be considered.

- The KPIs in the parent scorecards should be taken into consideration.

- Market applications should be considered.

- The determined KPIs must be specific and measurable.

- The cost-benefit balance of the investments required to measure KPIs should be taken into account.

- All necessary information seen in the KPI Information Chart about the determined KPIs should be clearly determined.

Prepared balanced scorecards of the company consisted of key performance indicators determined by considering the corporate strategy and the current roles and responsibilities of departments and units, as stated above. These indicators were also expressed as data summarizing the results of the activities performed by the relevant units. These indicators were;

- Associated with strategic goals,

- Representing the roles and responsibilities of the relevant department and unit and their priority activities,

- Defined in detail and clearly formulated,

- Determined to be measurable. Otherwise, the installation cost of the system infrastructure required for their measurement should have been below the total benefit to be provided,

- Acquiring a total number between 8 and 20 for each unit within the framework of effective performance measurement and management.

\section{Executing the SCPM and Monitoring the KPIs}

In order to manage the corporate performance system effectively, the organization paid a high attention to the matters detailed below:

- First of all, the basic function and purpose of the performance management system was shared with the personnel of the institution and tried to make sure that they were adopted by the employees. In this context, the senior management emphasized that the system does not only serve the purpose of measuring performance, but is also a monitoring and management tool.

- Key performance indicators have been updated at regular intervals, at least once a year, taking into account the job descriptions and updated processes and strategic business plan determined by the organization on an annual basis. It is critical for the continuity of the process to associate the updates to be made in the scorecards and related KPIs with the changes in strategy, role definitions and processes.

- Further, for each new department and unit established, new scorecards have been created without delay, taking into account the role and job descriptions. New KPIs have been defined as "financial", "customer", "processes" and "development" dimensions. It has not been neglected that the aforementioned scorecards and given targets were also reviewed at the same frequency and period as other KPIs.

- Key performance indicators have been measured and annually reported (Figure.5) by a separate department unit responsible for the corporate performance management system, under the General Manager, in order to prevent data manipulations that may occur over time.

- The department, which has been responsible for the performance management system, have measured and reported the KPIs defined in cooperation with the relevant units and departments and with the agreement of the senior management in accordance with the periods specified in the scorecards. A critical issue in this process was that an IT aided system infrastructure was established to ensure that the data required to measure performance are provided on time, accurately and in the desired format.

\section{R\&S}

Research Studies Anatolia Journal

Volume:4, Issue:2, April 2021 
- Ultimately, the performance measurement results have been shared with the entire organization in an accurate, fair and transparent manner. Within the framework of the results obtained, the strategy and objectives have been reviewed and improvement opportunities have been identified throughout the organization.

Figure 5. Example Reporting of a Scorecard

\begin{tabular}{|c|c|c|c|c|c|c|c|c|}
\hline \multicolumn{4}{|c|}{$\begin{array}{c}\text { Retail Banking Vice GM Scorecard } \\
\text { December, } 2019\end{array}$} & \multicolumn{5}{|c|}{ ヨ.므 } \\
\hline & $\mathbf{k m}$ & шесіит & STRATECY & TARCET & REAUSED & митоо & sCORE & \\
\hline & & 65.00 & & & & & 3.17 & \\
\hline & KP1 1.1. & 0.00 & 0.00 & 51.00 & 44.00 & $86.27 \%$ & 2.00 & (.) \\
\hline \multirow[t]{3}{*}{$=$} & KP1 1.2. & 6.00 & 0.00 & 25.00 & 22.90 & $91.60 \%$ & 3.00 & $\ddot{*}$ \\
\hline & KP11.3. & 3.00 & 0.00 & 7.83 & 7.32 & $93.49 \%$ & 3.00 & $\ddot{*}$ \\
\hline & KP1 1.4. & 6.00 & 21.30 & 20.00 & 20.10 & $100.50 \%$ & 3.00 & $\ddot{*}$ \\
\hline$=$ & KPH 1.5 . & 35.00 & 0.00 & 3.00 & 3.18 & $106.00 \%$ & 3.18 & $\ddot{*}$ \\
\hline \multirow{2}{*}{\multicolumn{2}{|c|}{$\begin{array}{l}\text { KP1 1.6. } \\
\text { KP1 1.7. }\end{array}$}} & 2.00 & 0.00 & 0.00 & 4.00 & & 4.00 & $d$ \\
\hline & & 2.00 & 0.00 & 0.00 & 4.00 & & 4.00 & $\Rightarrow$ \\
\hline \multirow[t]{2}{*}{ - } & KP1 1..8. & 3.00 & 1.24 & 1.24 & 0.96 & $77.42 \%$ & 2.00 & (.) \\
\hline & KP1 1.9. & 3.00 & 2.40 & 2.40 & 2.70 & $112.50 \%$ & 4.00 & $d y$ \\
\hline \multicolumn{2}{|c|}{$=\quad$ KP1 1.1.10. } & 5.00 & 0.00 & 100.00 & 0.00 & $0.00 \%$ & & \\
\hline \multicolumn{2}{|c|}{ 2. CUSTOMER } & 16.00 & & & & & 3.38 & \\
\hline \multicolumn{2}{|c|}{ F $\quad$ KPI 2.I. } & 5.00 & 0.00 & 7.45 & 7.06 & $94.77 \%$ & 3.00 & $\ddot{*}$ \\
\hline \multicolumn{2}{|c|}{$=\quad \mathrm{KPI} 2.2}$. & 0.00 & 0.00 & 0.00 & 21.29 & & & \\
\hline \multicolumn{2}{|c|}{$=\quad K P 12.3}$. & 3.00 & 0.00 & 31.00 & 36.00 & $116.13 \%$ & 4.00 & $\Rightarrow$ \\
\hline \multicolumn{2}{|c|}{ * $\quad$ KPI 2.4. } & 3.00 & 0.00 & 0.00 & 266.43 & & & \\
\hline \multirow{2}{*}{\multicolumn{2}{|c|}{$\begin{array}{c}\quad \quad \text { KPI 2.5. } \\
-\quad K P 1 \text { 2.6. }\end{array}$}} & 0.00 & 0.00 & 0.00 & 47.40 & & & \\
\hline & & 5.00 & 0.00 & 0.00 & $494,186.00$ & & & \\
\hline \multicolumn{2}{|c|}{ 3. PRocess } & 9.00 & & & & & 3.00 & \\
\hline \multicolumn{2}{|c|}{ KP1 3.1. } & 0.00 & 0.00 & 457.70 & 700.00 & $152.94 \%$ & 1.00 & $\mathbf{A}$ \\
\hline \multicolumn{2}{|c|}{ KP1 3.2.} & 3.00 & 0.00 & 0.00 & 4.00 & & 4.00 & $b$ \\
\hline \multicolumn{2}{|c|}{ KP13.3. } & 3.00 & 0.00 & 0.00 & 33.00 & & & \\
\hline \multicolumn{2}{|c|}{ KP1 3.4 . } & 3.00 & 50.40 & 40.70 & 44.70 & $109.83 \%$ & 2.00 & (*) \\
\hline \multicolumn{2}{|r|}{ 4. LEARNING \& DEVELOPMENT } & 10.00 & & & & & 3.50 & \\
\hline \multicolumn{2}{|c|}{$\begin{array}{ll}F & \text { KP1 4.1. } \\
\end{array}$} & 2.00 & 0.00 & 8.00 & 12.00 & $150.00 \%$ & 5.00 & $q$ \\
\hline \multirow{2}{*}{\multicolumn{2}{|c|}{$\begin{array}{l}\quad K P 14.2 \\
\quad K P 14.3 . \\
\end{array}$}} & 2.00 & 0.00 & 6.50 & 8.00 & $123.08 \%$ & 2.00 & (*) \\
\hline & & 6.00 & 0.00 & 0.00 & 50.20 & & & \\
\hline
\end{tabular}

\section{CONCLUSION}

Balanced Scorecard as a tool to meet the strategic planning and performance evaluation needs of businesses, it is also a performance management system that provides dynamic harmony with the organization's value system and strategy. BSC also evaluates employees' performances according to organization strategic priorities and encourages employees to act in accordance with company objectives.

Organization performance is a multi-dimensional structure. In this structure, satisfying only the interests and expectations of partners and shareholders is not enough for the sustainable competitiveness of the organizations, employees and customers should also be satisfied. Thus, the BSC model evaluates the performance of the firm by considering not only the financial dimension, but also customer, internal processes and learning ang growth dimensions. Establishing the structure of these four perspectives, making interconnections with each other, creating objectives, measures, targets and initiatives and finally stating the relationship between these dimensions and the vision and strategies of the organization are necessary to obtain the promised benefits of BSC.

Thus, a real business case example is shown in this study about of the implementation of the BSC system in a multinational bank in Turkey. Step by step, the BSC implementation process is explained in details including, creation of the strategic plan and the interlinkages of BSC with these plan, starting of a business unit to manage the BSC process, creation of the scorecards and KPIs in an inclusive way, defining the all necessary information of unique KPIs, setting the target values 
of these KPIs, establishing an IT-Aided BSC System, collecting the realization data of the KPIs, and finally reporting the realized performances to the relevant organization members online.

This BSC performance management system obviously supported the organization along its strategic goals that the bank has gained long-term competitive strategic advantage in the banking sector of Turkey. Apparently, BSC has helped to organization to harmonize the performance of employees with the strategic objectives of the organization. Consequently, the bank outperformed in the finance league and finally got a place amongst the top ten banks, which was the strategic objective since 2010 .

This study is among the very rare examples of a real BSC implementation in a business organization and has a genuine value for both academicians and practitioners. The results will be helpful for both to implement the BSC in action step by step harmoniously with the strategic plans and performance management systems of particular organizations.

Future studies might focus on the integration of individual performance management and BSC performance management system. Also, longitudinal studies might shed light on the cause-effect relationship of the BSC performance management system and strategic success of companies.

The study has some limitations as well. The data of this study was derived from the former head of SCPM business unit in the bank. Thus, there might be a positive bias about the success of the BSC implementation in this particular organization. To overcome this issue, managers of other departments, employees and customers of the bank might have given some valuable information about the advantages and disadvantages of the system.

\section{REFERENCES}

Ağca, V. and Tunçer, E. (2006). Çok boyutlu performans değerleme modelleri ve bir balanced scorecard uygulaması. AKÜ, İktisadi İdari Bilimler Fakültesi Dergisi, 8(1), 173-193.

Akgül, B. A. (2004). İşletmelerde yeni performans ölçümleme sistemleri. Muhasebe Finans Dergisi, 24, 73-82.

Argüden Y. and Sağdıç, E. (2000). Balanced Scorecard, İstanbul, Arge Danışmanlık Yayınları.

Amaratunga, D., Baldry, D. and Sarshar, M. (2000). Assesment of facilities management performance: What next? Facilities, 18(1/2), 66-75.

Bruke, T. and Koonce, R. (1997). 12 principles of organizational transformation. Management Review, 86(8), 299-301.

Calabro, L. (2001). On balance: Almost 10 years after developing the balanced scorecard, authors Robert Kaplan and David Norton share what they've learned. The Magazine for Senior Financial Executives, February 1, 73-76. http://www.cfo.com/article/1,5309,2044,00.html (10.04.2020).

Coşkun, A. (2006). Stratejik performans yönetiminde performans karnesi kullanımı: Türkiye'deki sanayi işletmeleri üzerine bir araştırma. MÖDAV Muhasebe Bilim Dünyası Dergisi, 8(1), 127 153.

Cullen, J., Joyce, J., Hassal, T. and Broadbent, M. (2003). Quality in higher education: From monitoring to management. Quality Assurance in Education, 11(1), 5-14.

Ensari, H. (2005) 21. Y.Y. Okulları İçin Etkili Bir Stratejik Yönetim Aracı: Balanced Scorecard, İstanbul, Sistem Yayıncllık.

Ergün, Ü. (2002). Yönetsel performansın geliştirilmesinde yeni yaklaşımlar: mükemmellik modeli ve balanced scorecard. MÖDAV Muhasebe Bilim Dünyası Dergisi, 4(1), 1-19.

Fındıkçı, İ. (1999). İnsan Kaynakları Yönetimi, İstanbul, Alfa Yayınları.

\section{$\mathbf{R} \& S$}

Research Studies Anatolia Journal

Volume:4, Issue:2, April 2021 
Gautreau, A. and Kleiner, B. H. (2001). Recent trends in performance measurement systems: The balanced scorecard approach. Management Research News, 24(3/4), 153-156.

Güner, M. (2008). Bir stratejik yönetim modeli olarak balanced scorecard. Gazi Üniversitesi İktisadi ve Ídari Bilimler Fakültesi Dergisi, 10(1), 247 - 265.

Griffiths, J. (2003). Balanced scorecard use in New Zealand goverment departments and crown entities. Australian Journal of Public Administration, 62 (4), 70-79.

Kaplan, R. S. and Norton, D. P. (1992). The balanced scorecard: Measures that drive performance. Harvard Business Review, 70(1), 71-79.

Kaplan, R. S. and Norton, D. P. (1993). Putting the balanced scorecard to work. Harvard Businesss Review, 71(5), 134-141.

Kaplan, R. S. and Norton, D. P. (1996a). Translating Strategy into Action: The Balanced Scorecard, Boston, Massachusetts, Harvard Business School Press.

Kaplan, R. S. and Norton, D. P. (1996b). Using the balanced scorecard as a strategic management system. Harvard Business Review, 74(1), 75-85.

Kaplan, R. S. and Norton, D. P. (1997). Why does business need a balanced scorecard? Journal of Cost Management, 11(May-June), 5-11.

Kaplan, R. S. and Norton, D. P. (1999). Balanced Scorecard Şirket Stratejisini Eyleme Dönüştürmek, İstanbul, Sistem Yayıncllık.

Kaplan, R. S. and Norton, D. P. (2001). Transforming the balanced scorecard from performance measurement to strategic management: Part 1. Accounting Horizons, 15(1), 87-104.

Kaplan, R. S. and Norton, D. P. (2003). Balanced Scorecard, İstanbul, Sistem Yayıncılık.

Kaygusuz S. Y. (2005). Yönetim muhasebesinin performans yönetimi fonksiyonunda geldiği son nokta: Balanced scorecard (ölçüm kartı tekniği). İş, Güç, Endüstri İlişkileri ve Insan Kaynakları Dergisi, 7(1), 81-103.

Lee S. F. and On Ko, A. S. (2000). Building balanced scorecard with SWOT analysis and implementing 'Sun Tzu's The Art of Business Management Strategies” on QFD methodology. Managerial Auditing Journal, 15(1/2), 68-76.

Lopes, J. L. R. (1996). Corporate real estate management features. Facilities, 14(7/8), 6-11.

Neely, A., Bourne, M. and Kennerley, M. (2000). Performance measurement system design: Developing and testing process-based approach. International Journal of Operations \& Production Management, 20(10), 1119-1145.

Niven, P. R. (2002). Balanced Scorecard Step by Step: Maximizing Performance and Maintaining Results, New York, John Wiley \& Sons Inc.

Özbirecikli M. and Ölçer F. (2002). Strateji odaklı performans ölçüm sistemi, balanced scorecardBSC. İstanbul Üniversitesi Isşletme Fakültesi Dergisi, 31(2), 31-48.

Sağmanlı, M. and Ersen, Ç. (2001). Balanced scorecard ve stratejik odaklı kurum. Öneri Dergisi, $4(16), 127-132$.

Selvi, M. S. (2007). Müşteri Sadakati, Ankara, Detay Yayıncılık.

Sümerli Sarıgül, S. and Savsar, C. (2018). Çok Boyutlu Performans Değerlendirme Yöntemlerine Genel Bir Bakış. Özdaşlı, K., Demir, M. C., Tire, O., Arvas, İ. S., Odabaş, U. K., and Elagöz, İ. (Ed.), Sosyal, Beşeri ve İdari Bilimler Alanında Yenilikçi Yaklaşımlar, Ankara, Gece Kitaplığı, 113-141. 
Tangen, S. (2004). Evaluation and Revision of Performance Measurement Systems, Department of Production Engineering, The Royal Institute of Technology, Doctoral Thesis, Stockholm, ISBN 91-7283-860-4.

Walker, G. and Macdonald, R. (2001). Designing and implementing an HR scorecard. Human Resource Management, 40(4), 365-377.

Yılmaz, Y. (2007). Enformasyon teknolojisi yönetiminde dengelenmiş puan kartı. İstanbul, Doğuş Üniversitesi Dergisi, 8(1), 108-114. 